\title{
The fixer on the Pak-Afghan frontier: A de-skilled local labour in the global media
}

\author{
Syed Irfan Ashraf* \\ Department of Journalism and Mass Communication, University of Peshawar, Peshawar, Pakistan. \\ *Corresponding Author Emails: syedirfanashraf@uop.edu.pk | syedirfanashraf@gmail.com
}

\begin{abstract}
This study examines power misuse in global news production by focusing on the role of "fixer." Fixer is a local journalist who reports for global media on conflict-riddled areas or crisis situations. By interviewing forty fixers in Pakistan's war-hit Pashtun Belt along the Afghanistan border, I examine the challenges they face in working with the global media's visiting journalists before the start of the war on terror. Using Marx's concept of proletarianization which is a process in which capital transforms a great mass of society into daily wage workers, I reveal how the local journalist, who works as fixer, is not only de-professionalized, but his precarity, due to living in a war zone, also forces him to misuse his local news traditions in working for the global media. I argue that fixers are far more than just assistants to global media outlets. Not only are they all practicing journalists in their own right, but, as locals, they also are geographically better placed to use their experience than those journalists who are coming from outside the conflict zone. Yet, this subsidiary role automatically erases this distinction leading to the real fixers' de-skilling with consequences for the entire region.
\end{abstract}

Article History

Received:

May 2, 2021

Revised:

June 29, 2021

Re-revised:

July 14, 2021

Accepted:

July 30,2021

Published:

September 1, 2021

Keywords: Marxist theory, Pashtuns, FATA, Proletarianization, War journalism, Practicing journalists, News production, Global news Production, Precarity, Neo-imperialism

\section{How to Cite:}

Ashraf, S. A. (2021). The fixer on the Pak-Afghan frontier: A de-skilled local labour in the global media. Liberal Arts and Social Sciences International Journal (LASSIJ), 5(2), 1-16. https://doi.org/10.47264/idea.lassij/5.2.1

Publisher's Note: IDEA PUBLISHERS (IDEA Journals Group) stands neutral with regard to the jurisdictional claims in the published maps and the institutional affiliations.

Copyright: @ 2021 The Author(s), published by IDEA PUBLISHERS (IDEA Journals Group).

Licensing: This is an Open Access article published under the Creative Commons AttributionNonCommercial 4.0 International License (http://creativecommons.org/licenses/by-nc/4.0/) 


\section{Introduction}

On October $7^{\text {th }}, 2001$, the US-led war on terror against Al-Qaida started in Afghanistan and Pakistan. Weeks before the attack, Pakistan became a global media flashpoint where journalists from all around the world started pouring in. To stay closer to the border, most of these media crews either stayed in the federal capital Islamabad or they drove three hours to the northwest to lodge at Peshawar, a last Pakistani city situated some 40 kilometres away from Afghanistan's border. Rooms in Peshawar's only four-star hotel were all reserved. Because of official ban on foreign reporters' entry into the under assault tribal areas (the ex-FATA) bordering Peshawar, the foreign media relied on hiring local journalists as fixers.

The term fixer has prominently emerged in the post-9/11 journalism both in the academic (Palmer, 2019; Murrell, 2015; 2010; Palmer \& Fontan, 2007) and the non-academic literature (Barker, 2011; Witchel, 2004). Some have termed the fixer a foreign journalist's "paid best friend": and depicted him/her as "the local who interpreted, guided, and set up interviews" (Barker, 2011, p. 22; Blusse, 2012; Campbell, 2012). Others represented the fixer as "facilitator," and "handler" (Erickson \& Hamilton, 2006, p. 41; Crisell \& Starkey, 2006; Palmer, 2017; Lynch et al., 2010). Either way the term stands for a de-professionalized labour and does not represent those who fill this role to be identified with significant power in the decision-making process (Pendry, 2011; 2015; Palmer \& Fontan, 2007). Consequently, the fixers are interpreted as "generalists" (Palmer, 2019, p. 94) and are understood as a spineless "fluid body" (Erickson \& Hamilton, 2006, p. 41). This marginalized status is at odd with the Pakistani fixers' professional identity: almost all of them were experienced local journalists before they were hired as fixers in 2001.

Based on in-depth interviews with Peshawar-based fixers, I examined in this paper how the local reporters made sense of the term and what challenges did they face in working for global news media? I argue in this paper that fixers are far more than just assistants to global media outlets. Not only are they all practicing journalists in their own right, but, as locals, they also are geographically better placed to use their professional experience than journalists coming from outside the conflict zone. Yet, the term fixer automatically erases this distinction. The Marx's concept of proletarianization can best explain this process of reduction wherein capital transforms a great mass of people into wage labourers entailing consequence not confined to work settings (Marx \& Engels, [1848] 1978). While examining this de-skilling, the paper invokes Pakistani fixers' perspective, including my own journalistic insight as a local journalist-cum-fixer, to reveal the way news fixing wipes out a local contribution to global frontline news production.

This research inquiry is focused on the pre-war news reporting phase that starts in Pakistan from the second week of September 2001 and ends on the $7^{\text {th }}$ October 2001 - the day the U.S jets started the bombing of Al-Qaida hideouts in Afghanistan. Once the war started, the media crews left for Afghanistan to cover for the next two months the U.S jets bombing of Al-Qaida in Torabora caves. The pre-attack phase is important because it allows a unique focus on the emergent ethics of the local work relationship with global media crews. Building from a scratch, this initial trade interaction sets a roadmap for the media coverage of the militarized violence that remained continued in the region for over a decade (this war symbolically ended with the U.S troops' killing the Al-Qaida chief Osama bin Laden in Pakistan's garrisoned city of Abbottabad in 2011). 


\subsection{The local journalist: A potential fixer}

Peshawar's proximity to the war-torn Afghanistan has turned the city into a global hub of regional news since 1979, the year when the Soviet forces entered Afghanistan, which resulted in the start of a Petro-dollar Afghan Jihad (Saudi money and U.S arms enabled Pakistani military to raise a private resistance Islamist militia locally called Mujahidin). Main offices of Pakistani and international media are concentrated in the country's urban centres, i.e., Karachi, Lahore and Islamabad. Only bureau offices of the national media work in Peshawar city. The local media exists, but security centric policies of the country's military establishment do not allow commercial activities to grow in the region, which then cripple the local news economy. The local journalists are the only credible information source to report on the regional militarization while representing a lower tier in the organizational hierarchy of the national media system.

This researcher conducted a survey for his $\mathrm{PhD}$ work and found that out of the total twenty thousand Pakistani journalists, over two thousand works in Khyber Pakhtunkhwa province (only Pakhtunkhwa from hereafter). Around five hundred of this total is bureau reporters who are registered with the Peshawar press club. The remaining are district journalists reporting from each of the total thirty Pakhtunkhwa's districts. Over three hundred district reporters also work in seven agencies (districts) of the Federally Administered Tribal Areas (FATA). In 2018, FATA was officially merged in Pakhtunkhwa, but I will stick to the erstwhile separate status of the two administrative units because of my focus on the pre-merger local news history.

Around twenty-five million ethnic Pashtuns live in contemporary Pakistan (Pakistan Bureau of Statistics, 2017) which approximately is sixteen percent of the country's total 200.2 million population. The Khyber Pakhtunkhwa and erstwhile FATA are generally called Pashtun territories though other ethnic minorities also live in this bordering region. The local reporters, despite belonging mostly to the predominant Pashtun ethnic nationality, are the true representative of a life lived on the country's marginalized and militarized fringe. Their salaries are low which makes their status a victim of their placement. They are all potential fixers long before they opt to work as one.

Despite the overall marginalized status of the Pashtuns, the bureau reporter is relatively a better version of the local journalists. In other words, Peshawar is the local news hub, which makes the bureau reporters well connected with media grid inside and outside the country. Still, they are dependent for information on district reporters. On a typical workday, the bureau journalist contacts the district and tribal reporters for information before sending it to their respective national media outlets. The low-paid district and tribal reporters are the information repositories on their respective areas, but they are mostly not paid for this information sharing. What the district/tribal journalist expects in return is to avail future openings as a cog in the bureau reporters' network. Both the two groups of local bureau and district reporters often look for additional work to fill in for the deficiency of their overall low salaries and, therefore, fixing news becomes a need, not a choice.

In the 9/11 context, the relationship between the two groups took an exploitative turn in their working for the global media. Almost every global media network sent their star journalists and some competitive outlets like U.S.-based $C N N, N Y T, C N B C$, Japanese-based NHK and Qatari-owned Al-Jazeera, dispatched multiple teams (Gall, 2014). These visiting foreign journalists, while staying in Peshawar, hired the bureau reporters. The latter, in order to earn 
more than usual, extensively used their district cousins as their own unpaid fixers. This aspect of the local relations of news production is often missing from academic focus on the fixers' role in global frontline news production. Not only that fixer is often constructed as a limited function/role but tying this role to foreign journalists' apron also obscures the local reporter's agency as well as contribution, reducing them to an appendage status by default.

\section{Review of literature}

\subsection{The local news workers or children of lesser God}

Two books are written on news fixers in English language so far (as of April 13, 2021). First is Colleen Murrell's (2015) book entitled Foreign Correspondents and International News Gathering: The Role of Fixers and the second is Lindsay Palmer's (Palmer, 2019) recent study The Fixers: Local News Workers and the Underground Labour of International Reporting. Palmer had worked as TV producer before joining academia and Murrell also joined academia after working as correspondent using services of fixers. Both these authors are familiar with the representation of fixers' work but have not worked as fixers themselves. Therefore, their observation, analyses and insights are limited to actual fixers' narratives or international journalists handling of fixers as employers.

Using Bourdieu's field theory, Murrell's (2015) seminal contribution to the field of journalism is her emphasis on fixers' editorial contribution to news economy. Working as the fixer, a local news worker also learnt to follow journalistic objectivity, and "absorbed Western cultural values and Western news values" (Murrell, 2015, p. 151). Holding global economy, a saviour, the author argues that the "globalization has made possible" the teamwork relationship between the fixer and correspondent, while creating unprecedented work openings for local reporters in conflict scenario. "This tribe of news gatherers (be they correspondents or fixers)" seems to "have more in common with each other than with the general populace of the country in question (Iraq)" (p. 151). This "teamwork" approach, however, reduces the fixer to a faceless and nameless status, tying him/her to a correspondent's apron and reducing him/her to an appendage status in the corporate economy of 24/7 media machine.

Cautioning about limitations of the existing works on fixers, Palmar (2019) argues that earlier "studies are essential reading on fixers," but these studies "tend to foreground the perspectives of international journalists rather than the perspectives of fixers" (p. 4). Interviewing 75 fixers' from 39 countries, Palmer also interviewed 60 correspondents and news editors (mostly from Western countries) and did not limit the fixer role to a conflict zone. Palmar (2019) argues that the fixers' views, most of them belonged to postcolonial countries, "allude to the insidious ways in which the logic of colonialism continues to haunt their lives in the $21^{\text {st }}$ century..." (p. 5). Hence, Palmer (2019) found "the practice of international reporting...profoundly hierarchical despite the fact that it is also, by definition, profoundly collaborative" (p. 6). This cultural theory approach, however, indicates a contradiction in the author's work. The logic of colonialism, by its definition, hardly allows for any collaborative relationship in a sense that the oppressive system of colonial relationship reduces by default the colonized to an instrumental status. Also, Palmer draws parallels between fixers and colonial era "tour guides," "spies," and "interpreters." This treatment not only disconnects a fixer's local identity from their professional training and practices, but it also fixes them all into the spatial confines of the place they happen to occupy. 
In 2019, Journalism Studies published a special issue Reporting global while being local: Local sources of news for distant audiences (Mitra \& Paterson, 2019). Multiple studies in this special issue probed the premise of local-global news production and reproduced a theme that could be found common in earlier studies: local media workers (fixers) are indispensable part of the team of international journalists. In other words, “...there is a mutual learning process between the fixers and international reporters" (p. 1733). Some academics in the issue celebrate these local-global work ties while referring to fixers as "cultural translators and news gatherers" (Hoxha \& Andresen, 2019, p. 1733). Others look critically at the role (Allan \& Zelizer, 2004). All these studies, nevertheless, called fixers anything but fully-fledged journalists. Only Plaut and Peter (2019) mentioned in passing that fixers "are often journalists themselves" and, despite their teamwork with the journalists, "it is a relationship created, and generated, through the process of colonialism" (pp. 1699-1700). A recent study (Baloch \& Andresen, 2020) examined security challenges to Pakistani fixers while identifying the latter as full-time local journalists. But the authors (Baloch \& Andresen, 2020) did not break with the past research (Baha, 1978). In other words, all these studies reinforce the academic tradition of reducing the fixers to an appendage status to foreign correspondents. Because the academic understanding of fixers is mainly limited to the fixer and correspondent's relationship in work setting scenario, therefore, critical view could not be honed.

In their seminal work on the topic, Palmer and Fontan (2007) raise an important point regarding the academic treatment of fixer's role in news reporting that, ".... any assessment of the impact upon quality would need some independent data for the purposes of output comparison" (p. 22). Simply put, comparing the work of fixer or assessing the quality of their labour depends upon availability of enough data on the issue. Otherwise, what is so obvious on this topic is usually ignored. An academic and freelance British journalist Pendry $(2011 ; 2015)$ shares a tangential but important insight in the context of the Syrian conflict. Pendry (2015) argues that corporate media discourages freelance journalists from reporting on offshore war zones and hires instead Syrian reporters to do the job. The author argues that this tendency in global frontline news production degenerates the quality of work raising labour-related ethical questions. Despite this concern, the literature still reproduces the subordinate role while ignoring the fixers' professional experience, cultural knowledge and the shared properties of their local social networks. What then falls through the cracks of the academic analyses is a local journalist's transformation into a wageworker, a local labour de-skilling in global frontline news production.

\subsection{The fixer: A Marx's proletarian}

In Marxist analysis, a daily wageworker qualifies to be called proletarian but this definition neither hangs on a casual employment per se nor could be confined to a particular field as such. Uncertain work in free market economy is a general symptom of a larger malaise-a degeneration of life itself. Proletarianization is a process that stands for this degeneration. It is a relationship between capital and workers, where the proletariat, a wageworker, is reduced to selling his/her labour power, i.e., lifetime. For instance, journalists working for a private company, like teachers working for a private school, are proletarians in a sense that they are exposed to capital's constant urge for availing cheap labour. Though a journalist in a media house-like a teacher in a private school - has professional capital based on which s/he could be called petty bourgeois. But this knowledge worker status is not a stable position to define his/her class. For Marx, class is, like everything else in his dialectic, a relationship - there is no fixed proletariat as the industrial worker (although that is how commonly people talk about 
it - as a wage worker). In other words, the proletariat, like any part-time employees, is produced through a process of deskilling. This process of de-skilling happens in journalism through fixers and in the university through adjuncts, but both these two different forms of casual work are outcome of the same worldwide process of proletarianization-labour degeneration essential for running the production mills of capitalism.

Proletarianization, then, is a process through which capital transforms a news worker's labour power. It gradually forces a worker to lose his/her independent use of skill set while leading to the loss of dignity of a worker, a fragmentation followed by self-abuse, pain, anguish and frustration. Perhaps this is why Marx termed capital as inherently exploitative because this reduction of labourers does not stop at deskilling. Instead, this surplus generating process turns human life itself into a rich resource, a means for the end of capital--money. Proletarianization then is a transformation of a labour power into a gruelling process of capital making, a deskilling process in which capital appropriates labour at every point, subjecting a worker's embodied potentials to profit making motives. In commercial news economy, the emergence of the term fixer is a miniscule expression of this degenerative transformation.

\section{Research methodology}

\subsection{Recovering the local perspective}

This paper is a part of my larger Ph.D. study. In 2016-17, I carried out forty in-depth interviews with both sets of the local news reporters: bureau and district journalists. It was the time when Pakistan military announced to have dismantled the Al-Qaida-affiliated Taliban groups, which enabled me to interview these journalists by visiting them in the troubled districts of Pakhtunkhwa and FATA. The interviews were semi-structured, and the sample was purposive. Eighteen respondents are Peshawar based bureau journalists and the rest are district reporters. Two respondents are Islamabad-based journalists who had worked with the foreign journalists when the latter landed in Islamabad before visiting Peshawar to stay in the city. By including the two fixers from Islamabad, I aim to follow in detailed way how the local work culture developed in the pre-attack phase. All these local reporters have worked as fixers (some paid and others unpaid) in the pre-attack phase in 2001.

My respondents are all male (no female fixer worked in the initial phase of the war ranging from the second week of September to $7^{\text {th }}$ of October 2001). Some have been working in the region for the last forty years. Others joined the profession close to the year 2001. Their qualification level ranged from metric to masters. A few even had graduation degree in journalism and the rest were self-trained reporters. However, all of them knew functional English using which they worked with the global media. Because some of these respondents either still live in the conflict zone or work for the foreign media, therefore, I keep their names anonymous to avoid risks to their lives or jobs. The rest has consented to use their quotes with their actual names.

Unlike other academic works on fixers, this paper also uses my own insight as a Peshawarbased fixer. From the year 2006 to 2010, I worked as a bureau reporter for a respectable private national TV channel in Peshawar. From 2000 to 2006, I was a news editor in an English daily in Rawalpindi/Islamabad and also remained a media consultant in corporate sector. During this time, I frequently met my local colleagues in Peshawar and observed them working as fixers with foreign media. Once I started journalism in Peshawar, my own part time fixer work was 
a unique experience that I have documented elsewhere (Ashraf, 2020; 2018). Because of my journalistic work, I knew many of my respondents who were included in this study. This study is, therefore, different from other works on the topic because its analyses are informed by a fixer's own insight.

However, familiarity also breeds challenges. A few respondents in this study were reluctant to answer my questions. "You know better than me," said a district reporter while trying to skip my question about hierarchal form of field exploitation. Knowing well that I had been a bureau reporter, he seemingly did not want to offend his bureau colleagues with his remarks. To deal with this challenge, I use in this paper Critical Discourse Analyses (CDA) as a method to find hidden meanings in the interview text.

"Discourse" refers to the patterns behind language's social use. "Critical" stands for a probe of social inequality. This method provides a researcher with a toolkit to help examine a language's critical use, while revealing the way power and ideology are deployed in social interaction (Fairclough, 2003; Jorgensen \& Phillips, 2002). To make sense of metaphors, nouns, pronouns and other parts of speech, CDA allows triangulating text in its context. What the Pakistani reporters say about news "fixing" could be used as a resource (text) to examine local discourse within larger domain of the global news production (context). Before to go further, I make it clear that Pakistani fixers called their employers, who were all international journalists, as "foreign journalists." Therefore, I use the term foreign journalist as a collective noun for all kinds of journalists who visited Pakistan in the pre-attack phase and hired the fixers to report on the conflict zone.

\section{Analysis and discussion}

\subsection{The local hierarchy of global frontline news production}

Three themes emerged in my interviews with the local journalists. First, the local reporters did not know about the term fixer but they found the job similar to what they have routinely been doing as the local journalists. The second theme was the local journalists' sense of insecurity that they felt as fixers. They were treated as logistical labour that led to develop in them a sense of frustration about the role. The third theme relates to a hierarchical nature of exploitation in the global frontline news production: the visiting journalist hired the fixer but in so doing, they benefited from the entire human network of local news production.

\subsection{What "Fixers" stand for?}

In Pakistan, news fixing is a post 9/11 phenomenon. Only two respondents said that they were familiar with the term fixer before start of the "war on terror." Within days, however, the term became a buzzword. With media crew started pouring into the Peshawar city from all over the world, the global-local interaction not only kept the local hotels and restaurants busy in terms of merchandize or cultural interaction. But the rising heat of the impending war as well as the increasing flow of capital also paved way for an unreflective introduction of the term into the local vocabulary. "It was a windfall of dollars," said one bureau reporter who believed that he benefited from this initial gold rush-a payment these reporters received in dollars. News of the windfall reached from one local reporter to another and the enthusiasm it caused also motivated taxi drivers, waiters and students to try their luck. 
However, as time went by, the non-journalist fixers were getting aside. Only the local journalists were able to meet commitment of the job. Adept in the art of news reporting, the bureau reporters were frontrunners. Some of them said that they had received direct calls from the visiting journalists. "My employer somehow managed getting my number after he read my story in a local English daily," said a respondent. Some of the bureau reporters were already in contact with media outlets around the world and reported as freelance journalists for them on militarization in the region. However, majority of these respondents said that they visited the hotels where the foreign journalists were staying and asked for work as fixers. Getting the work was not difficult initially. It was quite usual for these fixers to work with more than one media crew from the same network at the same time. But this relaxes situation could not remain the same once the war started and the foreign journalists got eager not only to stay closer to the site of war, but also to access newsworthy information such as interviewing on the emerging situation die hard militant commanders or high-profile government officials.

Despite no familiarity with this term fixer, one bureau reporter said he "quickly" learnt how to work. Others also did not show any difficulty in acclimatizing with the work's terms and conditions. Almost all of the bureau reporters could speak and write English functionally and were well versed in Urdu, the national language of Pakistan. Pashtu, the local language, was their native tongue. Translation was not an issue, therefore. Though district reporters were less articulate in the use of English, most of them did not work in the initial phase. Only two of them said that they have worked as fixer before start of the actual war. The rest of the district news reporters worked with different global media outlets indirectly-through the offices of their Peshawar-based bureau colleagues. Working in the region for decades, these were all resourceful enough to enable the global media access local information. Their work hours varied between 3 to 10 hours a day, for which they initially charged from $\$ 200$ to $\$ 300$, which gradually came down to $\$ 100$.

Familiarity with work started in idea sharing meetings on almost daily basis. Some of these respondents said that they were asked by their employers to visit their hotels at night where the media crews gathered just after dinner or during the same time to plan for the next day. A few local bureau journalists said they met with their employers at lobbies of their respective hotels to chalk out plans. Most of the bureau reporters said that they heard the term fixer for the first time in these meetings. "I did not pay much attention to the term initially," said Liaquat Ali. He realized much later that the term is not as worthy to represent a local journalist. A few said they did not initially understand what the term actually meant. Attitude of some of their employers, however, made them gradually conscious of the term's condescending underpinnings. Not all employers, however, were the same. "Some of them were very friendly...they did not say much even if their expectations were not met by their fixers," said Jameel Orakzai who worked with two different employers at the same time. One of Orakzai's employers belonged to the world's leading wire services. He often asked the fixer to take him to places where he could take on camera what could make the audience feel a (cultural) difference, i.e., "burka clad women," "armed people," "turbaned tribal," "trucks, and rickshaws." The fixers said that they not only gradually came to know about their employers' expectations, but also started to know how to present local issues with a global perspective.

For these fixers competition between different media outlets emerged one of their main challenges. Not only that the visiting journalists, who worked for elite media outlets, especially from the U.S., broke each other's fixers by tempting them with offers of higher wages but the decision to hire a fixer was also not limited to the latter's professional news competence only. 
For example, fixers were also expected to inform their employer about whereabouts of the rival parties, a function not different than spying on others. "If the CNN crew wanted to attend an event, FOX's crew also expected their fixer to keep an eye on the situation," said a respondent. At times this competition became a matter of concern for these fixers. As they traditionally relied on sharing information, the fixers stayed in touch with each other on everyday basis. This was how they came to know about local anti-war local protests or pro-Al-Qaida demonstrations. But this collaboration was not always welcomed. Some of the fixers said that their employers got annoyed with them because they did not want their fixers to share information with others. Ijaz Ahmad worked with a TV crew for a month. But this relationship got sour once the crew stopped him from sharing contacts with his colleagues. "They (employers) often praised me for being a resourceful reporter but did not like my talking to local friends whose help I availed for accessing news." This approach of the employers was irritating for some of my respondents in this study.

Sometimes, fixers were expected by their employers to keep track of other foreign channels, promoting a sense of competition, which could not be isolated from the foreign journalists' own sense of insecurity. Reporting on offshore wars has always been considered "extremely competitive" by most foreign journalists and chances are more that they try to accrue maximum personal capital while expecting "fixers" to work wonders for them, a phenomenon that is especially acute in the age of celebrity TV journalists (Murrell, 2015, p. 68). "Fixers", therefore, are "an invaluable part of a newsgathering team; they are the ones who can pull proverbial rabbits out of hats" (Murrell, 2015, p. 78). For my research participants, however, the task of working with ambitious employers was intimidating, yet "fixers" handled this challenge not as part of teamwork but as a compulsion. In this way most of them added to the possibility of continuing their work for the next day.

\subsection{The paid and unpaid labour}

Though Peshawar was the centre of the emerging media circus, those districts lying in close proximity to FATA were brewing with pro-Al-Qaida and anti-War protests. Hundreds of religious seminaries were established in the entire region since the U.S sponsored Islamic Jihad of 1980s. Once the Red army was defeated in 1989, the Pakistani State's soft stance on religious militancy allowed thousands of radical students of these seminaries to assert their street power in support of Al-Qaida. Fixers were the foreign media credible independent news source to cover these protests. In other words, the local tradition of information sharing worked to the benefit of the visiting journalists allowing the latter to access the entire news network of the local reporters. Only a few bureau reporters said they paid a small amount to the district colleagues for seeking their help. The majority of the respondents said they did not pay any amount to their district colleagues despite availing their help. A couple of "fixers" said they had tried to convince their foreign employers to pay their district colleagues for the help they were extending, but this request fell on deaf ears.

Even in the case of payment to district colleague, the remuneration paid was meagre and only covered the expenses such as transport or food charges. But these payments did not exceed rupees 3,000 (US\$25). Working as part of a bureau reporter network as free or unpaid fixer, the district reporter was also always equally exposed to the amount of risk that a bureau reporter faced as a paid fixer. One district reporter from the Kurrum district said that he shared local information with a bureau journalist who visited him to cover an anti-war protest while working as a fixer. Once the fixer left, the district reporter started receiving threats from unknown people 
calling him from unfamiliar numbers. "They were intelligence operatives," he said, using the Pashtu term "mamagan" (uncles) for the sleuths. The district reporter was genuinely worried because "I knew that many foreign channels couldn't differentiate between anti-war protest and pro-Al-Qaida demonstrations." Later, the bureau reporter called the district reporter to inform him of receiving similar threats on telephone. While this news sharing practice remained intact despite its associated risks, the district reporters began to feel the heat of changing things because of their proximity to the frontlines of war-the expanding Al-Qaida influence into the bordering districts of Pakistan.

The lexical use of "mamagan" identifies the threatening nature of the local relations of news production: the bureau reporters visiting the conflict zone from Peshawar-while their foreign employers waiting back in hotels - and using the district reporters as their own unpaid fixers in pursuit of news about local anti-war protests or interviewing the Al-Qaida affiliated local Taliban groups. Both sets of the local reporters, however, were getting conscious of having been exposed. In Pashto language, the term "mama" not only stands for uncle or elder with authority to oversee you. But it also identifies those who monitor you like an "overlord." Thus, the term is both a sign of respect as well as an intimidation. The unpaid fixers' fear of "mamagan" was a serious threat, they represented a hyper precarious local tier in the commercial media ecosystem hierarchy.

Faced with this double whammy, communication was also the source of threat for the unpaid fixers. Al-Qaida fighters were on the run and were locally believed to have been using Kurrum's Zeran or Parachamkani ranges for escape. Stretched across FATA, these majestic mountains provided access to the Orakzai district in the south and Khyber (district) in the southwest via a strategic web of abandoned routes used by cross-border smuggling gangs to connect with Peshawar. Kurrum's green mountains turn barren, and its rocky roads grow dry and dangerous as they go deep into the South and North Waziristan agencies (districts). Reporting on these areas in the absence of backing from media organization makes news fixing a risky job. Likewise, the local reporters faced an increasing fear of State surveillance. Not only does it make sending news difficult outside the conflict zone, but this fear also led to mistrust. "We shared news with each other, but we knew that this information could create problems for us later," said Ali Hussain. Despite all these hurdles and risks, the two sets of the local reporters played a vital role in reporting for the global media on the war's build-up in the pre-attack phase.

\subsection{Labour categorization: A contested terrain}

In existing academic literature, "fixers" are valued for language skills (Palmer \& Fontan, 2007) and cultural capital such as contacts and familiarity with the site of reporting (Murrell, 2015). Fixers also are associated with providing their employers logistical services such as booking hotel or arranging taxicabs. But many respondents (around 18) in this study suggest otherwise. They guided their employers in finding restaurants or availing car service, but one respondent called this help "hospitality." "Let's suppose" he hypothesized, "I carry a camera tripod with my employer...I take it as load sharing (with a guest)," he argued.

But this camaraderie was not a general rule. One respondent said that "I did not carry any logistical load ... my work would be limited to journalism related stuff." Another respondent (fixer) said that he was making editorial choices in those instances in which he was part of a decision-making. "I fixed interviews... I also helped (my employer) in suggesting 
questionnaires, did translations, explained the context." By offering these perspectives, these fixers wanted to powerfully support the editorial nature of their work. Yet, only a few fixers said they received credit for their contributions; some said their clients rejected their requests for a by-line. Those who received this credit had already done much work as fixers and were respected figures in the field. This local reputation put them in a position of bargain. Those who did not have this prior professional value as a distinguished local journalist, they accept what is offered to them.

A few "fixers" (5 respondents) said their chances of getting a by-line increased with increasing work experience, though they still depended upon their relationship with the employer. In other words, many of these fixers got by-lines in the later phases of their work relationship with foreign journalists, depending on the former's ability to win the latter's trust. One bureau journalist said that the employer he worked with was stationed in India working as bureau chief for the UK-based Daily Telegraph. This fixer was given a by-line if the foreign journalist needed his help from Pakistan, but he received no by-line when he worked together physically with the client inside Pakistan. This working relationship identifies the absence of organizational work ethics to recruit local labour, a lack which adds to the decision-making position of a visiting foreign reporter.

These different arguments make it clear that the boundaries between the respondents' logistical work and their cultural responsibilities were blurry. Though in those specific instances in which the fixers exercised their agency by enforcing their own work ethics, they did try to draw rudimentary boundaries around their work or at the very least define work ethics to make sure that their consent has a determining effect. But this agency varied from person-to-person and context-to-context and could not be translated as these fixers having cultural capital. Organizational support at the level of journalism, as a field, is necessary for the fixers to accumulate in order to claim cultural capital, something they lack by default.

\subsection{Local journalists losing occupational pride}

When asked if the research participants felt secure working as fixers, this question invited stories of pain and anguish. My research participants apparently used this risky job as a step to cultivate foreign contacts in the hope of exceling in the field. This forward-looking approach worked for some of them, though at a cost they do not seem ready to pay easily. Aon Sahi is a senior Islamabad-based journalist and have worked with different Western media for over seven years before he was elevated to become a stringer, a journalist who is given professional recognition on his/her contribution to news stories but that is what s/he gets apart from a meagrely fixed amount in regular salary. Is working as a stringer better than languishing as a fixer? Sahi started work as stringer with the Los Angeles Times team that won a Pulitzer Prize in 2015, something he considered to have been impossible had he been working as a fixer. His sense of insecurity pushed him to hide his own limitations, lest his employers count them as his incapacity to work. For Sahi, the term fixer describes his own weakness that was rooted in a sense of deprivation; something he got over once he was promoted to a relatively stable position as stringer. Sahi said:

If I was asked for one quote, I worked hard to provide two. If they asked for two contacts, I put extra effort in my work to arrange four. I faced dangers as if they were normal as if risk-taking was my job... the foreign journalists I worked with 
were often well-mannered...but I found them eager to switch from one fixer to another...my worst fear was being replaced.

Sohail Rahman, an Islamabad-based Pashtun journalist, started working with a global TV crew. Initially, his employer encouraged him to stay with them in a posh hostel where they also dined together. But these privileges were withdrawn soon. First, he was asked to eat on his own and then his room was cancelled. This forced Rahman to rent a cheap hostel room far away from the posh hotel. Some fixers said that they found the hotel management, where the visiting journalists were staying, discouraging them from entering specific areas where foreign journalists gathered to drink or dine, restricting their ability to do their jobs. After working for around eight months with Islamabad-based foreign teams, for example, Rahman said:

Fixers met their employers around 7 a.m. at the Marriot... After coming back from the field, they would stay late into the night working on translations...even though we were in the hotel, none of us could afford to eat the expensive food...we had to wait and eat at home after finishing the work, sometimes late at night.

The more accustomed the foreign journalists became to the local environment, the less caring their relationships with fixers became. Paid \$200 per day initially, their remuneration was reduced to $\$ 100$ and finally $\$ 50$. At this point the fixer quit. Some respondents got uneasy while I asked them to interpret the term fixer for me. Sahi worked with American journalist Kim Barker, a foreign correspondent for The Chicago Tribune. Based on her professional experiences, Barker wrote a book called The Taliban Shuffle, which was later made into a Hollywood film called Whisky Tango Foxtrot. "I asked Kim," said Sahi, "not to refer to me as a "fixer'...she did mention me in her book, but as a translator." Another respondent said, "Working as 'fixer' made me feel as if I were a pimp. As if I were just arranging terms between two kinds of people: the journalists and the contacts." These local journalists rejected the term fixer and referred to themselves as journalists.

\subsection{De-skilling journalism in embodied form}

This paper offered a local perspective on the term fixer and recounted the experiences of the local reporters working with global media/foreign journalists in the run-up to the U.S. bombing of Al-Qaida hideouts in Afghanistan. Using their previous experiences, the local news reporters accessed events in conflict situation and helped their employers in conceptualizing as well as executing the idea. Every aspect of this experience is journalistic and, therefore, editorial in orientation. But labour bias is inherent in genesis of the term "fixer."

Now ubiquitous in media production globally, the emergence of the fixer is a product of capitalist expansion. While a few media conglomerates control, the news channels of distribution and exhibition the world over, a scattering of local journalists are hired in conflict and crises riddled marginalized areas as fixers. They do the risky work of news productionas I have shown in the context of Pakistan where the local reporters' news pursuits enabled the foreign journalists of the global media to access distant and dangerous bordering areas. Gathered at the command of corporate media, they help produce news contents to aid the celebrity anchor or parachute journalists. No ethical or professional considerations are enforced whatsoever. Once the media event is over, the fixer also disassembles. This is how the fixer is produced when local journalists are deskilled and de-professionalized-their expertise, 
knowledge, cultural capital and local connections are stripped away to produce a faceless and nameless daily wageworker in service of the $24 / 7$ media news economy.

This finding puts a question mark around the term fixer. We should not forget that fixers are local journalists in many parts of the world. Even if they are not, the skills they use are common in journalism found in their respective localities. This makes their news experience journalistic in essence. Yet, they are reduced to a de-facto status, a proletarianization process that starts with a worker selling his labour on the market in return for wages. But labour is not an ordinary commodity. A worker selling his labour means taking his "own hide to market and now has nothing else to expect but-a tanning" (Marx, [1867] 1976, p. 280). Bureau journalists visiting hotels and restaurants to ask for job as fixer refers to this "tanning." Their living labour was on sale as a commodity without any consideration to their security. Though this lack is inherent in labour-capital dynamics, but it also reflects who actually calls the shot. Journalism, as a field, clearly privileges regular journalists over fixers and, therefore, reveal the way power and prestige - rooted in the visiting journalists' nationality as well as media capital-delimits autonomy of the local journalists to produce cheap de-professionalized labour, a proletarian with a flexible and disposable status.

The term fixer, therefore, represents the de-skilling of journalism itself in its embodied form. It identifies a local journalist's reduction into a daily wageworker. Working in this role, the local reporters were paid to use their journalistic tools and techniques in pursuit of risky news, but they were excluded from the organizational backing of the corporate media that automatically deprive them of their professional recognition. This lack, as said before, is suggestive of the fact that fixers don't have a cultural capital and represent a logistical function without any ethical underpinnings. Given this precarious work status, one theme I found constantly running through the entire paper: the tension between the role of the fixer and the person who fills it. Though this role is often represented in academic literature as a professional opportunity, however, what the paper reveals is that a decision to become a fixer is not a true choice for the local reporters in Pakistan. For them, fixer is a default position that turns actual journalists into nameless and faceless workers by engaging them in what is over simplistically called a "teamwork" relationship. The term fixer, in other words, is a misnomer. This term, while explicitly epitomizing the existential struggle of the actual Pakistani journalists, represents interests of the global media news economy.

The decade's long violence in Pakistan in itself is part of a proletarianization process in which the war brings conditions of extreme scarcity to dispossess the local population, transforming a mass of people into wage labourers, a cheap work force. In other word, the imperialist war since the 1979 Afghan Jihad has not only routinized the coming and going of the foreign journalists but the emergence of the term fixer reveals a degrading status of labour. For the local journalists, the war has become bread and butter. Making a living through getting news out into the global arena forces them to turn into fixers. This form of reporting, however, also reinforces war: not making difference between pro-Al-Qaida demonstrations and anti-war protests was not just an urge to earn a daily wage. But this tendency also carried threatening consequences for the local population: the war.

\section{Conclusion}

The paper revealed the structural nature of the hierarchical power misuse in the global frontline news production. In other words, the appearances of paid and unpaid fixers are different 
expressions of labour marginalization embedded in this exploitative process of proletarianization. A global journalist hiring a fixer gets access to an entire network of local reporters. In this hierarchical process, which rules the profession of journalism in Pakistan's conflict riddled parts, the misuse of local news traditions is structurally embedded in this unseen exploitation of paid or unpaid "fixers." This unethical culture, emerging out of this long-standing news economy in Pakistan, not only exposes real people to undue common risks in the line of the fixer's unrecognized duty, but also hides from our view the way the news fixing role wipes out a local contribution to global frontline news production

In this proletarianization process, however, the fixer is not a mere victim. He is also a social agent who multiplies, by default, the consequences of reporting from a marginalized trade position in two crucial ways. First, in a bid to earn a daily wage from reporting on the imperialist war, the fixer, in turn, takes part in reproducing the same hierarchical news structure of which he is a victim. In other words, by becoming a cog in 27/7 global media machine the fixer, as a role, not only helps an employer to get access to the entire local network, but this fixer-employer relationship also always goes beyond just giving exploitation a collective local character: this marginalized role helps the global media vying for control over events to decide who gets to tell the local stories. Secondly, in misusing local news traditions, the fixer, while exploiting his colleagues (unpaid fixer) in carrying out this existential struggle, also by default exposes himself and many others, including his own family members, to undue risks.

In view of this crucial role of fixers, it has become vital for the fixers to come forward and share their own stories to reveal the downside of the global media in the emerging economy of risky news. However, the journalists we interviewed here were reluctant to write about their experiences in any form. They apparently were afraid of living an opinionated life in a conflict zone. For future researchers, therefore, the fixers' endeavours must not be merely focused on the local news workers' exploitation or marginalization, but a second tier of analysis must also be focused on the existing set of research approaches to go beyond just offering an uncritical examination of war and crisis journalism/reporting. This approach will help to know what fixers say about their work and what challenges they undergo living in embodied relationships to the conflict zone. In other words, the role of fixer is an outcome of a war/crisis situation. Therefore, the fixer, as a real person or a professional role, needs to be examined not in an isolation from a conflict zone. Instead, this role should be probed in the extended relationship to violence or crisis.

\section{Declaration of conflict of interest}

The author(s) declared no potential conflicts of interest(s) with respect to the research, authorship, and/or publication of this article.

\section{Funding}

The author(s) received no financial support for the research, authorship and/or publication of this article. 


\section{References}

Allan, S., \& Zelizer, B. (2004). Rules of engagement: Journalism and war. In S. Allan, \& B. Zelizer (Eds.), Reporting war: Journalism in wartime (pp. 3-22). Routledge.

Ashraf, S. I. (2018). How experience becomes a journalistic asset? A local reporter's perspective to understand conflict-sensitive reporting in the troubled Pashtun belt of Pakistan. Central Asia Journal, 83, 173-190. https://docs.google.com/viewer?url=journals.uop.edu.pk/view_paper.php?paper_id= 1194\&embedded=true

Ashraf, S. I. (2020). Media, Molvi and Malala: A perspective on the ethics of news fixing. The Journal of Humanities \& Social Sciences, XXVIII(2), 1-20. http://journals.uop.edu.pk/papers/JHSS.pdf

Baha, L. (1978). Struggle of Journalism in the Frontier Province 1900-1930. Islamic Studies Journal, 17(3), 217-229. https://www.jstor.org/stable/20847078

Baloch, K., \& Andresen, K. (2020). Reporting in conflict zones in Pakistan: Risks and challenges for fixers. Media and Communication Journal, 8(1), 37-46. https://doi.org/10.17645/mac.v8i1.2514

Barker, K. (2011). The Taliban Shuffle: Strange days in Afghanistan and Pakistan. Scribe.

Blusse, J. (2012, May). The fixer's place in the field: The role of fixers in foreign news reporting from China. Unpublished Master Thesis, Faculty of MA Program at the University of Amsterdam.

Campbell, M. (2012). In Afghanistan, international coverage relies on local links. In B. Sweeney \& E. Beiser (Eds.), Attacks on the Press in 2011 (pp. 38-43). Committee to Protect Journalists. $\quad$ https://cpj.org/2012/02/"fixer's"-on-front-lines-inafghanistan.php\#more

Crisell, A., \& Starkey, G. (2006). News and local radio. In B. Franklin (Eds.), Making the local news: Local journalism in context (2nd ed., pp. 16-26). Routledge.

Erickson, E., \& Hamilton, J. M. (2006). Foreign reporting enhanced by parachute journalism.
Newspaper
Research
Journal,
$27(1)$
$37-47$. https://doi.org/10.1177/073953290602700104

Fairclough, N. (2003). Analysing discourse: Textual analysis for social research. Routledge.

Gall, C. (2014). The wrong enemy: America in Afghanistan 2001-2014. https://www.youtube.com/watch?v=zA8fzs8H3sw

Hoxha, A., \& Andresen, K. (2019). The development of roles in Kosovo: From fixers to $\begin{array}{llll}\text { journalists. } & \text { Journalism } & \text { Studies, } & 20(18),\end{array}$ https://doi.org/10.1080/1461670X.2019.1639539

Jorgensen, M., \& Phillips, L. (2002). Discourse analysis as theory and method. Sage.

Lynch, G., Palmer, G. F., \& Hamilton, J. M. (2010). In many wars, by many war correspondents. Baton Rouge, Louisiana State University Press.

Marx, K. (1867). Capital: A critique of the political economy (B. Fowkes, Trans.; Vol. 1). Penguin Books.

Marx, K., \& Engels, F. (1848). Manifesto of the communist party. In R. C. Tucker (Ed.), The Marx-Engels reader (2nd ed.). Norton.

Mitra, S., \& Paterson, C. (2019). Reporting global while being local: Local sources of news for distant audiences. Journalism Studies, 20(12), 1671-1678. https://doi.org/10.1080/1461670X.2019.1639540

Murrell, C. (2010). Baghdad bureaux: An exploration of the interconnected world of fixers and correspondents at the BBC and CNN. Media, War and Conflict, 3(2), 125-137. https://doi.org/10.1177/1750635210363338 
Murrell, C. (2015). Foreign correspondents and international newsgathering: The role of fixers. Routledge.

Palmer, J., \& Fontan, V. (2007). Our ears and our eyes: Journalists and "fixers" in Iraq. Journalism, 8(1), 5-24. https://doi.org/10.1177/1464884907072419

Palmer, L. (2017). Lost in translation: Journalistic discourse on news "Fixers". Journalism Studies, 19(9), 1-18. https://doi.org/10.1080/1461670X.2016.1271284

Palmer, L. (2019). News 'fixers': The underground economy of international reporting. Oxford University.

Pendry, R. (2011). Sub-contracting newsgathering in Iraq. The International Journal of Communication Ethics, 8(3/4), 14-20. http://communicationethics.net/subjournals/free article.php?id=00003

Pendry, R. (2015). Reporter power: News organizations, duty of care and the use of locally hired news gatherers in Syria. Ethical Space, 12(2), 1-12. https://kar.kent.ac.uk/60966/

Plaut, S., \& Klein, P. (2019). "Fixing" the journalist-fixer relationship: A critical look towards developing best practices in global reporting. Journalism Studies, 20(12), 1696-1713. https://doi.org/10.1080/1461670X.2019.1638292

Statistics, P. B. (2017). The sixth housing and population census. Pakistan Bureau of Statistics, Islamabad. https://www.pbs.gov.pk/content/demographic-and-research

Witchel, E. (2004). The fixer New York: Committee to Protect Journalists (CPJ). http://cpj.org/reports/2004/01/ 